\title{
ANALISIS IMPLEMENTASI KEBIJAKAN MANAJEMEN BERBASIS SEKOLAH PADA MADRASAH ALIYAH DI KABUPATEN LUWU UTARA
}

\author{
MUH. TAKDIR ${ }^{1}$, MUHAMMAD YUSUF², ALIMUDDIN³ \\ STKIP Muhammadiyah Bogor ${ }^{1}$, Universitas Muhammadiyah Palopo ${ }^{2}$, Institut Agama \\ Islam Negeri Palopo 3 \\ Email: muh_takdir@stkipm-bogor.ac.id,muhammadyusuf@umpalopo.ac.id, \\ alimuddin@iainpalopo.ac.id
}

(Article History)

Received October 05, 2020; Revised November 23, 2020; Accepted November 28, 2020

\begin{abstract}
:
The objective of research is to analyze and to describe the implementation of School-Based Management (MBS) policy, the factors supporting and constraining the implementation of MBS policy, and the response of teachers to the implementation of MBS policy at Madrasah Aliyah in Luwu Utara District. The precise location of research is at MA Muhammadiyah Balebo, MA Al-Falah Lemahabang and MAN Luwu Utara. Research design is qualitative with descriptive method analysis through Edward III theory. Data collection techniques involve interview, observation and documentation. Data are subjected to the analysis which involves data reduction, data presentation, and verification/conclusion. The conclusion is managerial competence of principal and active participation of whole stakeholders, especially community with their moral and material supports based on demand of madrasah, are main factors to implement MBS policy.
\end{abstract}

Keywords: Policy Implementation, MBS, School Management

\section{PENDAHULUAN}

ksistensi pendidikan memiliki pengaruh yang substansial terhadap proses pembentukan karakter dan pola pikir manusia. Oleh karena itu, pendidikan menjadi kebutuhan primer karena dalam fungsinya yang murni mampu mencetak sumber daya manusia yang berkualitas dan produktif. Dalam sudut pandang inilah, maka memajukan kualitas pendidikan dan sumber daya manusia merupakan usaha strategis untuk membentuk suatu masyarakat yang berperadaban tinggi. Sehingga muncul sebuah istilah bahwa 'Pendidikan tidak pernah usang'. Pesan ini dapat dimaknai bahwa pendidikan sebagai sebuah proses pembentukan kecakapan fundamental secara intelektual dan emosional yang matang, akan tetap dibutuhkan manusia, karena tanpa itu manusia tidak akan pernah layak disebut ‘manusia' (Ahmad, 2011). Manusia sebagai makhluk Tuhan yang diberi kelebihan berupa akal pikiran dituntut untuk membuktikan kualitasnya dalam kehiduapan nyata. Kualitas tersebut dapat ditunjukkan dengan berbagai macam potensi manusia seperti kemampuan berpikir, berkarya dan melahirkan sebuah terobosan 
baru dalam membentuk peradaban yang berkemajuan. Tugas inilah yang kemudian menuntut pendidikan untuk memainkan peranannya yang begitu dominan dan strategis dalam kehidupan manusia. Dominasi pendidikan tersebut dibutuhkan konsep integrasi dalam membentuk pendidikan masa depan (Demirel, 2019).

Undang-Undang Sistem Pendidikan Nasional (Nomor 20 Tahun 2003) sebagai salah satu rujukan konstitusional dalam penyelenggaraan pendidikan di Indonesia telah mengamanahkan kepada para pelaku pendidikan khususnya pada tingkat satuan pendidikan untuk dapat lebih mandiri dalam mengoperasikan penyelenggaraan kegiatan pendidikan. Berdasarkan hal tersebut menurut Fattah, (2012) bahwa dalam reformasi pelaksanaan manajemen pendidikan diperlukan reformasi filosofi dan nilai-nilai dasar pendidikan dalam pembangunan pendidikan nasional yang sesuai dengan kultur masyarakat Indonesia yang majemuk, sehingga pengambilan kebijakan pada tingkat satuan pendidikan merupakan sebuah langkah strategis bagi pimpinan (kepala sekolah) untuk dapat meningkatkan mutu pendidikan dalam meraih sebuah prestasi sekolah yang berkualitas. Salah satu indikator dari sebuah sekolah yang bermutu adalah terletak pada pengambil kebijakan di internal lembaga pendidikan tersebut. Proses pengambilan kebijakan dalam meningkatkan mutu pendidikan menuntut kemampuan manajerial kepala sekolah sebagai tuntutan untuk melakukan perubahan (Gu, Sammons, dan Chen, 2018).

Kepala sekolah pada tingkat satuan pendidikan memiliki wewenang dalam menentukan sebuah kebijakan sekolah/madrasah. Namun, seiring dengan reformasi sistem pendidikan dari sentralistik menjadi desentralistik, maka pendelegasian wewenang merupakan unsur yang paling utama Musanna dan Bahri, (2011). Oleh karena itu, pendelegasian wewenang merupakan konsepsi diberlakukannya konsep Manajemen Berbasis Sekolah/Madrasah (MBS/M) sebagai acuan dasar dalam menyelenggarakan proses pendidikan dengan melibatkan seluruh stakeholder sekolah/madrasah (guru, staf, komite sekolah, orang tua siswa, dan masyarakat umum, termasuk kelompok industri), sehingga dalam hal tersebut, dibutuhkan sebuah analisis yang mendalam dalam melahirkan sebuah kebijakan pada tingkat satuan pendidikan mulai dari perumusan kebijakan sampai pada tahap penilaian (evaluasi).

Menurut Wohlstetter dan Mohrman dalam Majir (2012) bahwa secara luas MBS berarti pendekatan politis untuk mendesain ulang organisasi sekolah dengan memberikan kewenangan dan kekuasaan kepada partisipan sekolah pada tingkat lokal guna memajukan sekolah. Keberhasilan sekolah dalam menerapkan kerja MBS ditentukan oleh kemampuan sekolah menjalankan fungsi-fungsi yang didesentralisasikan di sekolah secara efektif. Menurut Dwiningrum (2011) bahwa dalam penerapan MBS secara sistemik dan fungsional, kepala sekolah beserta stakeholder lainnya dituntut untuk memahami kerangka kerja yang menjadi landasan dalam sistem MBS, yaitu: (1) perencanaan dan evaluasi program sekolah, 
(2) pengelolaan kurikulum, (3) pengelolaan proses belajar mengajar, (4) pengelolaan ketenagaan, (6) pengelolaan peralatan dan perlengkapan, (7) pengelolaan keuangan, (8) pelayanan siswa, (9) hubungan sekolah-masyarakat, dan (10) pengelolaan iklim sekolah. Lazwardi (2018) menyatakan bahwa faktor dominan dalam implementasi MBS adalah partisipasi siswa, tenaga pendidik, masyarakat, dan ketersediaan sarana.

Hasil pengamatan sementara peneliti terkait pelaksanaan MBS pada beberapa madrasah aliyah di Kabupaten Luwu Utara baik yang berstatus negeri maupun swasta pada umumnya belum dipahami secara baik oleh mayoritas kepala sekolah/madrasah. Pengelolaan sistem pendidikan pada tingkat satuan pendidikan masih dijalankan sesuai dengan instruksi dari pemerintah yang bertanggung jawab dalam penyelenggaraan pendidikan baik dari dinas pendidikan maupun dari Kementerian Agama. Oleh karena itu, realisasi konsep desentralisasi yang mengacu pada implementasi konsep MBS yang memberikan kewenangan kepada sekolah/madrasah dalam mengelola sistem pendidikan belum dioptimalkan berdasarkan konsep dan teori yang ada. Di samping itu, kemampuan kepala sekolah dalam mengakomodir seluruh stakeholder sekolah/madrasah belum berjalan secara baik.

Bertitik tolak dari hal tersebut, maka dalam penerapan konsep MBS/M harus senantiasa didukung oleh kemampuan profesionalitas para stakeholder pada setiap satuan pendidikan, khususnya kepala sekolah/madrasah selaku pimpinan. Kemampuan kepala sekolah/madrasah dalam sistem manajerial yang mampu melahirkan sebuah kebijakan yang produktif adalah bagian dari persoalan terimplementasinya konsep MBS secara efektif dan efisien, sehingga dalam hal ini peneliti tertarik untuk melihat secara mendalam terkait bentuk implementasi kebijakan MBS, faktor pendukung dan penghambat implementasi kebijakan MBS, dan respon guru terhadap implementasi kebijakan MBS pada Madrasah Aliyah di Kabupaten Luwu Utara.

Bentuk implementasi kebijakan MBS dalam penelitian ini dianalisis melalui Teori Edward III. Berdasarkan pendapat Edward III tersebut, implementasi dapat diartikan sebagai tahapan dalam proses kebijaksanaan yang berada di antara tahapan penyusunan kebijaksanaan dan hasil atau konsekuensi-konsekuensi yang ditimbulkan oleh kebijaksanaan itu (output, outcome). Dalam model yang dikembangkannya, Edward mengemukakan ada empat faktor kritis yang mempengaruhi keberhasilan atau kegagalan implementasi, yaitu komunikasi, disposisi, sumber daya, dan struktur organisasi (Akib, 2010). Komunikasi merupakan proses penyampaian informasi dari komunikator kepada komunikan yang dalam hal ini bagaimana kepala sekolah menyampaikan informasi terkait isi dan sasaran kebijakan kepada seluruh stakeholder. Disposisi adalah kecenderungan sikap dari pengambil kebijakan yang sangat berperan dalam keberhasilan implementasi kebijakan. Sumber daya adalah segala sesuatu yang dapat medukung keberhasilan 
implementasi kebijakan seperti SDM, anggaran, informasi, dan sebagainya. Sedangkan struktur birokrasi merupakan aspek struktur organisasi yang memiliki wewenang dalam implementasi kebijakan yang dalam prosesnya terdapat mekanisme (SOP) atau garis instruksional yang kadang menciptakan kompleksitas. Keempat hal tersebut dapat digambarkan sebagai berikut:

Gambar 1. Teori Edward III

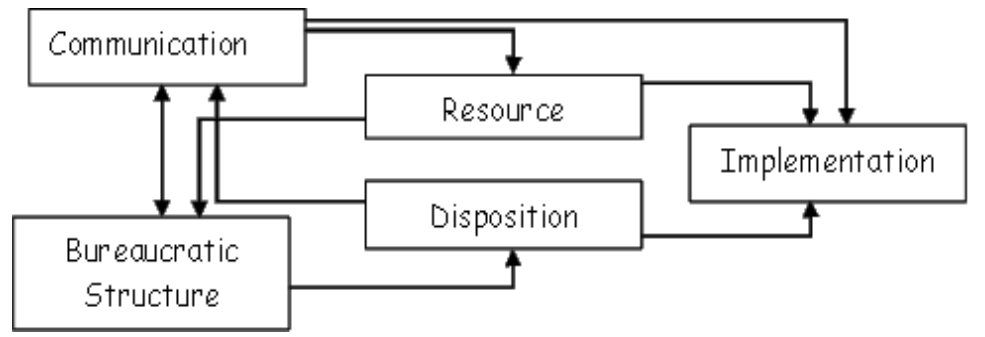

Sumber: Windari, Darwin, dan Purba (2018)

Tujuan dari penelitian ini adalah untuk menganalisis dan mendeskripsikan bentuk implementasi kebijakan manajemen MBS, faktor pendukung dan penghambat implementasi kebijakan MBS, dan respon guru terhadap implementasi kebijakan MBS pada madrasah aliyah di Kabupaten Luwu Utara. Sedangkan manfaatnya terbagi menjadi dua yaitu manfaat secara teoritis dan praktis. Secara praktis manfaat penelitian ini adalah memberikan sumbangsih pemikiran pada pengelola pendidikan pada umumnya dan kepala sekolah/madrasah pada khususnya selaku pimpinan atau top leader dalam satuan pendidikan untuk dapat mengimplementasikan konsep manajemen berbasis sekolah/madrasah terkhusus pada madrasah aliyah (MA) dalam setiap pengambilan kebijakan di sekolah/madrasah. Sedangkan secara teoritis adalah memberikan informasi bagi pengelola pendidikan khususnya kepala sekolah/madrasah beserta stakeholder yang lain agar memahami secara komprehensif tentang konsep manajemen berbasis sekolah/madrasah seperti yang tertera dalam Undang-Undang Nomor 20 Tahun 2003 tentang Sistem Pendidikan Nasional (SISDIKNAS).

\section{METODE PENELITIAN}

Penelitian ini menggunakan pendekatan kualitatif dengan metode deskriptif analisis. Lokus penelitian adalah lembaga pendidikan tingkat madrasah aliyah yang berlokasi di Kabupaten Luwu Utara Propinsi Sulawesi Selatan, yaitu MA Muhammadiyah Balebo, MA Al-Falah Lemahabang dan Madrasah Aliyah Negeri Luwu Utara. Data yang diperoleh terdapat dari dua sumber, yaitu data primer dan sekunder. Data primer dalam peneltian ini adalah data yang dikumpulkan berdasarkan permasalahan utama yang terkait dengan bentuk implementasi kebijakan MBS, faktor pendukung dan penghambat implementasi kebijakan MBS dan respon guru terhadap implementasi kebijakan MBS. Data primer yang diperoleh melalui wawancara dan studi dokumentasi tersebut dianalisis berdasarkan Teori Edward III. Sedangkan data sekunder diperoleh dari data yang sudah ada dan 
mempunyai hubungan masalah yang dapat diteliti yang meliputi literatur-literatur yang ada baik berbentuk dokumen maupun pengamatan peneliti. Data dikumpulkan menggunakan teknik interview (wawancara), observasi (pengamatan), dan dokumentasi. Partisipan dalam penelitian ini antara lain kepala sekolah, guru, staf, siswa, orang tua, perwakilan komite sekolah, pengawas sekolah, dan Kepala Bidang Pendidikan Islam Kementerian Agama Kabupaten Luwu Utara. Selanjutnya data yang terkumpul dianalisis dengan menggunakan analisis data model Miles and Huberman. Aktivitas dalam analisis data kualitatif dilakukan secara interaktif dan berlangsung secara terus menerus sampai tuntas, sehingga datanya sudah jenuh. Adapun aktivitas dalam melakukan analisis data yaitu mereduksi data, menyajikan data dan menyimpulkan. Untuk menguji keabsahan data yang diperoleh dilakukan uji triangulasi.

\section{HASIL PENELITIAN DAN PEMBAHASAN}

\section{Bentuk Implementasi Kebijakan MBS di MA Muhammadiyah Balebo, MA Al-Falah} Lemahabang dan MAN Luwu Utara

Berdasarkan hasil temuan di lapangan bahwa kebijakan MBS sudah diimplementasikan di masing-masing madrasah. Namun, efektifitas dalam pengambilan kebijakan oleh kepala madrasah dalam memberdayakan seluruh sumber daya madrasah belum berjalan secara optimal, khususnya di MAN Luwu Utara. Sedangkan di MA Al-Falah Lemahabang dan MA Muhammadiyah Balebo peran kepala madrasah dalam mengakomodir seluruh pihak untuk menciptakan efektifitas proses pembelajaran di madrasah sudah dilakukan, tapi butuh konsistensi dan arah pengembangan yang berkelanjutan (continues development).

Beberapa peran yang ditunjukkan oleh kepala madrasah dalam efektifitas manajemen di madrasah antara lain pengambilan kebijakan yang bersifat buttomup, kedekatan dengan masyarakat sebagai partner pengembangan madrasah, dan partispasi aktif dalam pendampingan kegiatan pengembangan kesiswaan. Selain itu, juga dibuktikan dengan tingginya motivasi guru dalam menjalankan tugas serta partisipasi masyarakat yang sangat peduli terhadap kemajuan madrasah. Beberapa agenda manajemen yang berorientasi pada implementasi kebijakan MBS, antara lain manajemen kurikulum, manajemen tenaga pendidik dan kependidikan, manajemen sarana dan prasarana, manajemen kesiswaan, manajemen pendanaan, manajemen iklim madrasah yang kondusif, dan partisipasi masyarakat.

\section{Manajemen Kurikulum}

Hasil temuan terkait dengan manajemen kurikulum pada madrasah yang menjadi lokus penelitian ini dapat diketahui melalui hasil wawancara pada beberapa partisipan, sebagai berikut:

"Kurikulum di madrasah ini sedikit berbeda dengan madrasah lain.

Karena kita di sekolah Muhammadiyah, maka kita memiliki mata pelajaran wajib, yaitu mata pelajaran kemuhammadiyahan. Tetapi untuk 
buku panduannya kita beli dari buku panduan yang sudah ditetapkan oleh Majelis DIKDASMEN Muhammadiyah". (WW/M1 Partisipan 1)

"Kalau kurikulum yang kita gunakan di sini itu memadukan antara kurikulum dari dinas pendidikan untuk mata pelajaran umum dan untuk mata pelajaran keagamaan seperti aqidah akhlak, fikih, Qur'an hadis, sejarah peradaban Islam, dan bahasa Arab kita mengacu pada kurikulum Kementerian Agama. Kalau untuk mata pelajaran umum juga ada buku pegangan yang langsung dari Kementerian Agama juga. Jadi, semuanya kita gunakan. Tinggal nanti guru yang sesuaikan dengan kebutuhan materi dan kesesuaian dengan tingkatan kelasnya. Selanjutnya untuk pengembangan kurikulum itu kita serahkan pada masing-masing guru bidang studi tapi sebelumnya kita lakukan rapat. Bagi guru-guru biasanya kita ikutkan di kegiatan MGMP atau KKG biar teman-teman guru bisa lebih meningkatkan kemampuan mengajarnya." (WW/M2 Partisipan 2)

"Untuk kurikulum yang kita gunakan tetap K-13. karena inikan sudah ketentuan pemerintah. Tapi, dalam kurikulum ini kan hanya sebagai panduan bagi madrasah yang nanti dikembangkan sendiri sama guruguru. Selanjutnya, pengembangan kurikulum kita lebih fokuskan ke program semeter yang dilakukan masing-masing guru bidang studi, dan di setiap akhir semester kita tetap lakukan evaluasi untuk proram semester berikutnya". (WW/M3 Partisipan 1)

Berdasarkan informasi hasil wawancara tersebut sebagai hasil temuan di lapangan bahwa pengembangan manajemen kurikulum sudah dilakukan, namun belum nampak sisi keunggulan yang bisa diciptakan sebagai ciri khas masing-masing madrasah tersebut. Kurikulum yang digunakan masih bersifat normatiif, artinya bahwa kurikulum yang sudah ditetapkan oleh pemerintah belum dilakukan pengembangan yang mencirikan kekhasan. Kajian tematik pada kurikulum mestinya dikaji dan dikembangkan berdasarkan karakteristik dan sumber daya yang menjadi potensi untuk dilakukan inovasi agar penyampaian materi dapat ditransformasi kepada siswa secara efektif dan maksimal.

Kurikulum merupakan perangkat dasar dalam menjalankan aktifitas proses pembelajaran di sekolah/madrasah, sehingga kemampuan pihak madrasah, dalam mengembangkan kurikulum yang telah ditetapkan oleh pemerintah merupakan sebuah keharusan. Di samping sebagai indikator dalam menciptakan proses pembelajaran yang relevan dengan keadaan lingkungan dan kondisi siswa. Dengan demikian, menurut (Asmani, 2013) bahwa manajemen kurikulum harus senantiasa bersifat dinamis, responsif, dan antisipatif.

\section{Manajemen Tenaga Pendidik dan Kependidikan}

Manajemen tenaga pendidik dan kependidikan merupakan salah aspek yang didesentralisasikan melalui implementasi MBS. Hasil temuan terkait manajemen tenaga pendidik dan kependidikan dapat diketahui berdasarkan hasil wawancara, sebagai berikut: 
"Masalah MBS, di madrasah ini kita sudah terapkan, bahkan sejak dibangunnya madrasah ini karena madrasah ini merupakan swadaya dari masyarakat sekitar. Sampai saat ini MBS masih dijalankan, buktinya kita disini masih tetap melangsungkan kegiatan belajar yang guru-gurunya masih semangat dan Ikhlas untuk mengabdi di madrasah ini walaupun honornya masih sangat kecil bahkan kurang sesuai dengan tugas mengajar. Tapi alhamdulillah kebersamaan kita di madrasah ini cukup bagus karena setiap permasalahan selalu kita bicarakan baik dalam bentuk rapat maupun melalui pendekatan pribadi". (WW/M1_Partisipan 1)

"Untuk tenaga pendidik yang ada di madrasah kita rata-rata sudah S.1. Tetapi masih ada empat orang guru yayasan yang masih alumni SMA tapi saat ini mereka sedang kuliah ambil jurusan PAl, tapi kemampuan mereka saya pikir tidak jauh beda dengan alumni $\mathrm{S.1}$ bahkan kemampuannya bisa lebih karena mereka itu alumni pesantren. Jadi, ijazahnya hanya ijazah pondok. Yang empat orang itu kita berikan mata pelajaran keagamaan seperti, Qur'an hadis, aqidah akhlak, fikih, sejarah Islam, dan bahasa Arab. Bahkan, juga memiliki kemampuan kaligrafi sebagai kegiatan ekstrakurikuler. Untuk perekrutan guru-guru kita serahkan pada yayasan, tapi memang rata-rata guru disini mayoritas dari suku Jawa, begitu juga siswa, karena mamang pendiri dan pengurus yayasan dari orang Jawa juga". (WW/M2_Partisipan 1)

Hasil wawancara tersebut menunjukkan bahwa dalam manajemen tenaga pendidik dan kependidikan dilakukan berdasarkan kebutuhan madrasah, hanya saja pada sisi lain belum memenuhi standar kualifikasi tenaga pendidik dan kependidikan yang telah ditetapkan oleh pemerintah. Menurut Mulyasa (2012) bahwa manajemen tenaga pendidik dan kependidikan mencakup perencanaan pegawai, pengadaan pegawai, pembinaan dan pengembangan pegawai, kompensasi, promosi dan mutasi, pemberhentian pegawai, dan penilaian pegawai. Sementara itu, Takdir (2019) menyatakan bahwa sebagai upaya peningkatan kualitas kinerja tenaga pendidik dan kependidikan perlu dilakukan perencanaan SDM pendidikan yang mengacu pada peraturan perundang-undangan, yaitu kompetensi pedagogik, kepribadian, sosial, dan profesional. Berdasarkan hasil temuan terkait manajemen tenaga pendidik dan kependidikan belum berjalan secara optimal seperti yang dikemukakan oleh Mulyasa (2012) dan Takdir (2019).

Peran kepala madrasah merupakan tolak ukur dalam meningkatkan kinerja dan pengaturan tugas dan tanggung jawab para guru maupun staf di madrasah. Kurang maksimalnya proses pembelajaran yang berlangsung di madrasah disebabkan oleh rendahnya kompetensi guru dalam mengelola pembelajaran yang lebih berkualitas. Berdasarkan hasil penelitian di masing-maisng madrasah tersebut belum ada yang memiliki kegiatan pengembangan guru yang secara internal dilakukan oleh pihak madrasah. Semua bentuk kegiatan yang dapat menunjang kompetensi guru hanya dilakukan melalui kegiatan Kelompok Kerja Guru (KKG), 
Musyawarah Guru Mata Pelajaran (MGMP), Kelompok Kerja Madrasah (KKM), serta kegiatan lain seperti seminar, pelatihan, workshop dan yang semacamnya yang itu dilakukan di luar madrasah.

\section{Manajemen Sarana dan Prasarana}

Mengenai manajemen sarana dan prasarana sebagai temuan dalam penelitian ini dapat diketahui berdasarkan beberapa hasil wawancara dengan partisipan, sebagai berikut:

"Kalau fasilitas kita disini masih sangat kurang karena kita hanya mengharapkan sepenuhnya pada bantuan pemerintah, dan untuk mendanai pengadaan fasilitas juga sangat kekurangan. Untuk honor guru saja pas-pasan. Karena bantuan yang kita terima disesuaikan dengan jumlah siswa. Siswa disini rata-rata dari golongan yang kurang mampu, jadi untuk pungutan biaya sama sekali tidak ada. Cuma disini sebagian siswa mendapatkan Bantuan Siswa Miskin (BSM). Jadi, untuk perawatan fasilitas kita tinggal gunakan yang ada sebaik mungkin karena kita memang terkendala di pendanaan. Tapi syukurnya di tempat kita setiap ada yang mau dikerjakan orang tua siswa responnya cukup baik untuk membantu kalau ada kerusakan yang mau diperbaiki". (WW/M1_Partisipan 3)

"Untuk pengadaan sarana dan prasarana di madrasah kita selain dari bantuan pemerintah juga dari bantuan masyarakat. Contohnya, pembangunan pagar keliling itu merupakan swadaya dari orang tua siswa dan donatur. Itu disebabkan karena masyarakat sangat percaya dengan pengembangan di madrasah. Nah, untuk bantuan gedung dan peralatan itu masih bantuan pemerintah. Tinggal kita di madrasah tinggal memanage sesuai dengan keperluan". (WW/M2_Partisipan 1)

Hasil wawancara tersebut juga diperkuat dengan hasil studi dokumentasi, sebagai berikut:

Tabel 1. Daftar Sapras di MAN Luwu Utara

\begin{tabular}{c|l|c|c|c|ccc}
\hline No. & \multicolumn{1}{|c|}{$\begin{array}{c}\text { Jenis } \\
\text { Prasarana }\end{array}$} & $\begin{array}{c}\text { Jumlah } \\
\text { Ruang }\end{array}$ & $\begin{array}{c}\text { Jumlah } \\
\text { Kondisi } \\
\text { Baik }\end{array}$ & $\begin{array}{c}\text { Jumlah } \\
\text { Kondisi } \\
\text { Rusak }\end{array}$ & \multicolumn{2}{|c}{ Kategori Kerusakan } \\
\cline { 5 - 8 } & & 12 & 12 & - & - & - & - \\
\hline 1. & Ruangan Kelas & 12 & - & - & - & - \\
2. & Perpustakaan & 1 & 1 & - & - & - & - \\
3. & Laboratorium & 2 & 2 & - & - & - & - \\
4. & Kantor & 1 & 1 & - & - & - & - \\
5. & Ruang Guru & 1 & 1 & - & - & - \\
6. & Mushollah & 1 & 1 & - & - & - & - \\
7. & WC/Toilet & 5 & 5 & - & - & - & - \\
8. & Sarana & 2 & 1 & 1 & - & - & \\
& & Olahraga & & & & &
\end{tabular}

Sumber: Hasil Dokumentasi, 2020 
Hasil temuan peneliti terhadap manajemen sapras yang ada di madrasah yang menjadi lokus penelitian menunjukkan bahwa dalam perencanaan dan pengadaan sapras selain bantuan dari pemerintah, juga melibatkan partisipasi masyarakat. Hanya saja ketersediaan dan pemanfaatan fasilitas dalam proses pembelajaran belum optimal. Dengan kata lain, bahwa dalam proses pembelajaran para guru lebih cenderung menggunakan model tekstual melalui buku panduan. Sementara fasilitas seperti perpustakaan, laboratorium, halaman dan pekarangan madrasah dan fasilitas lain seperti alat peraga pembelajaran belum dimanfaatkan secara maksimal. Dengan demikian, keberadaan sarana dan prasarana di masing-masing madrasah hanya sebatas pelengkap yang belum dimaksimalkan dalam menunjang kegiatan pembelajaran yang lebih efektif dan efesien. Alsayyari, Et. Al, (2019) menyatakan bahwa dalam manajemen dan penggunaan operasional sarana dan prasarana sebaiknya menyesuaikan dengan kebutuhan agar prinsip efektifitas dan efesiensi dapat terwujud.

\section{Manajemen Kesiswaan}

Hasil studi menunjukkan bahwa manajemen kesiswaan yang ada di madrasah yang menjadi lokus penelitian ini sudah dilakukan dengan baik. Tapi pada beberapa hal masih ada kekurangan perlu untuk ditingkatkan lagi khususnya dalam layanan pembelajaran siswa, baik yang yang kurikuler, kokurikelur dan ekstrakurikuler. Hal tersebut seperti pada hasil wawancara berikut:

“Keadaan siswa disini, alhamdulillah sejak saya masuk dari tahun 2003 ya baik. Hanya jumlah siswa kita memang kurang siswa karena adanya sekolah umum negeri yang terus dibangun oleh pemerintah. Hanya kita syukur ya karena siswa kita selalu Iulus $100 \%$ setiap ujian nasional. Untuk kedisiplinannya, kita apa namanya dekati saja anak-anak supaya bisa lebih akrab, anak-anak tidak liar. Pendekatan seperti ini kita lakukan dengan anak-anak. Kalau masalah sanksi itu tetap kita kasih kalau ada yang melanggar tata tertib. Itu pun sekarang harus hati-hati juga karena nanti kena hukum perlindungan anak". (WW/M3_Partisipan 1)

"Untuk masalah prestasi kita sangat prioritaskan. Jadi setiap ada undangan lomba selalu kita utus anak-anak untuk mengikuti. Tapi sebelumnya kita tunjuk guru yang mamang punya kemampuan untuk membimbing. Untuk kegiatan pramuka disini kita sudah dapat kepercayaan dari kapolres sebagai anggota saka bhayangkara teraktif. Sehingga setiap ada undangan selalunya kita yang ditunjuk wakili kab. Luwu Utara. Nah, prestasi lain yang pernah kita dapatkan di MTQ tingkat kabupaten cabang Cerdas Cermat AI-Qur'an (CCQ) bisa dilihat pialanya. Juga setiap tahun kita selalu ikuti lomba PORSENI tingkat Kabupaten dan hampir setiap item lomba kita dapat. Dan juga kemarin ada 3 siswa kita yang lolos ke provinsi untuk lomba olimpiade di Kementerian Agama Provinsi Sulawesi Selatan untuk mata pelajaran fisika, biologi dan ekonomi... semua itu saya pikir tidak lepas kerja sama guru-guru dan siswa sendiri. Nah, supaya anak-anak tambah semangat selalu kita 
berikan bonus tambahan dari sekolah, begitu juga guru yang mendampingi”. (WW/M2_Partisipan 1)

"Ya lumayan bagus, karena belajarnya setiap hari kalau pagi di sekolah juga ada pelajaran pondok pelajarannya biasa sore dan malam. Juga di sini kita sangat akrab sama teman-teman dan juga dengan guru. Kalau kegiatan ekstrakurikuler, banyak sekali. Untuk kegiatan olahraganya seperti bola kaki, voli, takrow, bulu tangkis dan tenis meja. Juga ada tapak suci, hizbul wathan, latihan pidato atau ceramah, dan tadarus Al Qur'an. Nah, kalau belajarnya kadang-kadang gurunya tidak masuk mengajar. Terus kalau di sini ada yang melanggar aturan biasanya dipanggil guru ke kantor dan dikasih sanksi biasanya disuruh membersihkan, tapi pernah juga ada yang langsung dikeluarkan dari pondok. (WW/M1_Partisipan 5)

Berdasarkan hasil penelitian di tiga madrasah bahwa kemampuan kepala madrasah dalam menciptakan lingkungan madrasah yang memiliki keunggulan dalam bidang akademis maupun non-akademis sudah baik, namun untuk perlu ditingkatkan. Kegiatan yang sudah diprogramkan perlu dikembangkan dengan berbagai strategi yang benar-benar mampu menghasilkan prestasi. Menurut Mulyasa (2012) tujuan dari manajemen kesiswaan adalah untuk mengatur berbagai kegiatan dalam bidang kesiswaan agar kegiatan pembelajaran dapat berjalan lancar, tertib dan teratur, serta mencapai tujuan pendidikan sekolah. Artinya bahwa dengan adanya manajemen kesiswaan yang tertib dan teratur secara signifikan akan berpengaruh terhadap peningkatan prestasi siswa sebagai indikator sekolah/madrasah yang berkualitas.

\section{Manajemen Pendanaan}

Manajemen pendanaan merupakan salah satu unsur yang sangat urgen dalam keberlangsungan proses pembelajaran. Mengenai pengelolaan keuangan pada madrasah, khususnya yang menjadi lokus penelitian ini dapat diketahui berdasarkan hasil wawancara, sebagai berikut:

"Kalau untuk pendanaan madrasah sebagian besar dari bantuan pemerintah, seperti dana BSM, BOMM, gratis, dan ada juga tunjangan bagi guru yang bukan PNS, yaitu tunjangan fungsional yang biasanya guru-guru terima tiga bulan sekali. Tapi, kalau untuk pembangunan fisik biasanya kita buatkan proposal untuk bantuan rehabilitasi gedung dan Alhamdulillah kita sudah pernah dapat. Selain itu, juga biasanya dari donatur Muhammadiyah. Kalau dari orang tua kita tidak paksakan karena kita mengerti kondisi ekonomi mereka. Untuk pungutan siswa itu hanya menjelang semester sebanyak Rp 30.000,- dan ujian nasional bagi kelas 3 untuk tahun kemarin dikenakan Rp 400.000,- per anak". (WW/M1_Partisipan 1)

“Untuk mengatur masalah keuangan sepenuhnya kita serahkan kepada bendahara. Saya taunya hanya sekadar memberikan disposisi. Terus kita di sini sangat menjaga namanya pengelolaan keuangan, karena ini masalah yang sangat sensitif. Jadi, untuk pembiayaan selama setahun 
kita adakan pembahasan mengenai sumber dan sasaran dana yang itu dituangkan dalam rapat RAPBS yang diadakan setiap awal tahun ajaran. Nah, untuk menjaga image yang kurang baik mengenai pengelolaan keuangan, setiap bulan keadaan keuangan dilaporkan oleh bendahara biar tidak ada yang berprasangka negatif. Untuk pemberian honorer guru itu setiap bulan diberikan sesuai dengan jumlah jam mengajar, kalau kita disini hanya Rp 7.500,- per jam. Juga biasanya kalau ada sisa anggaran untuk pembangunan gedung misalnya, itu kita bagi rata sama semua guru dan staf biar tidak ada kecurigaan". (WW/M2_Partisipasi 1)

"Kalau pendanaan kita di sini sepenuhnya dari anggaran DIPA dan dana gratis. Jadi sama sekali tidak ada dari bantuan siswa, semuanya gratis. Kita juga tidak bisa melakukan pungutan karena memang sudah ada instruksi dari gubernur tapi saya sudah lupa suratnya. Bahkan siswa kita yang masuk kategori miskin, itu kita berikan beasiswa miskin yang memang sudah dari pemerintah langsung yang memang untuk masyarakat yang kurang mampu. Bahkan, sebagian anak-anak kita disini yang rumahnya jauh itu kita kasi uang transportasi biar tambah semangat datang ke sekolah sekaligus sosialisasi bagi masyarakat biar tidak kekurangan siswa". (WW/M3_Partisipasi 1)

Menurut Asmani (2013) bahwa manajemen keuangan berkaitan dengan pencatatan pendapatan dan pengeluaran yang sesuai dengan aturan main, aktif dalam menggali dana dan menyalurkannya sesuai dengan prosedur, serta dilengkapi dengan laporan rutin mingguan, bulanan, tengah semester, satu semester, dan tahunan. Berdasarkan hasil pengamatan yang peneliti dapatkan bahwa manajemen keuangan pada tiga madrasah tersebut, telah melakukan manajemen keuangan sesuai dengan kebutuhan madrasah itu sendiri.

Hasil temuan ketiga madrasah tersebut, belum sepenuhnya memenuhi ketentuan dalam manajemen keuangan seperti yang dikemukakan oleh Asmani (2013). Khususnya peran aktif pihak madrasah dalam menggali sumber pendanaan di luar dari bantuan pemerintah. Sedangkan untuk pelaporan keuangan menurut pengamatan peneliti sudah dilakukan. Hal tersebut dibuktikan dengan adanya buku pelaporan di masing-masing bendahara terkait pemasukan dan pengeluaran keadaan dana madrasah.

\section{Iklim Madrasah}

Upaya dalam efektifitas implementasi MBS/M adalah tata kelola iklim madrasah yang kondusif. Pengaturan iklim madrasah yang dapat menunjang aktifitas pembelajaran yang kondusif dapat diketahui berdasarkan hasil wawancara, sebagai berikut:

"Kalau untuk fasilitas kita di sini alhamdulillah sudah cukup memadai. Fasilitas olahraganya ada, perpustakaan, laboratorium komputer dengan IPA, luas lokasi yang cukup ditambah dengan pendanaan dari pemerintah yang menurut saya cukup besar dibanding madrasah lain yang ada di Luwu Utara. Cuma apa ya sepenuhnya belum maksimal. Makanya biasa 
guru kurang disiplin datang mengajar juga kedisiplinan siswa yang masih bisa dibilang kurang tertib. Kalau untuk komunikasi antar sesama guru ya sudah baik, Cuma namanya juga manusia kadang-kadang ada persilangan pendapat yang itu biasa membuat komunikasi kurang bagus". (WW/M3_Partisipan 3)

“Untuk menjaga ketertiban di madrasah ini kita berlakukan tata tertib. Nah, tata tertib itu bukan dari madrasah yang putuskan, akan tetapi kita undang semua orang tua beserta yayasan dan komite untuk kita rapatkan dan hasilnya itulah yang kita sahkan sebagai aturan yang mengikat bagi siswa. Jadi, apabila ada siswa yang melanggar kita berikan sanksi sesuai dengan aturan. Selain itu, juga disini kita adakan kerja sama dengan SMA Negeri 1 Bone-bone untuk pembinaan siswa yang sulit diatur. Kalau ada siswa kita disini yang nakal itu kita masukkan di SMA Negeri 1 Bone-Bone begitu juga sebaliknya, tapi siswa bersangkutan tetap siswa kita hanya saja kegiatan belajarnya tidak di madrasah. Nanti pada saat ujian akhir kita tarik kembali ke madrasah begitu juga yang dari SMA Negeri 1 BoneBone. Itu sudah kita jalankan sekitar 4 tahun dan alhamdulilah cukup berhasil. Tapi apabila ada siswa yang kita ikutkan program tersebut tapi masih juga berulah. Itu sudah kita kembalikan ke orang tuanya terserah mau disekolahkan di mana, yang jelas kita sudah angkat tangan. Terus untuk kontrol siswa bukan hanya dilakukan di madrasah, tapi juga saat di luar. Apabila ada informasi yang kita dengar dari luar bahwa siswa kita misalnya terlibat minum minuman keras, konsumsi narkoba, pergaulan bebas, mencuri, berkelahi atau malakukan hal-hal yang mengganggu ketertiban masyarakat itu langsung kita tindaki sesuai dengan tata tertib yang berlaku di madrasah, dan itu sudah sering terjadi". (WW/M3_Partisipan 3)

"Untuk masalah kondisi sekolah, saya pikir aman-aman saja. Hanya terkadang anak-anak biasa berkelahi, tapi saya pikir itu wajar, namanya juga anak-anak. Tapi kalau ada masalah begitu langsung kita tindaki sesuai dengan tata tertib yang berlaku, biasanya diamankan sama satpam itu kalau ada anak-anak yang ribut-ribut. Kalau bicara kenyamanannya sih ya lumayan. Karena antara teman-teman guru kita baik-baik saja. Sedangkan kebersihannya, disini kita sudah programkan setiap pagi jum'at diadakan baksos bersama. Tapi untuk menjaga kebersihan setiap harinya setiap kelas juga punya jadwal kebersihan untuk tiap pagi menyapu sebelum belajar". (WW/M1_P.1)

Hasil temuan pada tiga madrasah bahwa upaya pihak madrasah dalam menciptakan iklim yang kondusif sudah dilakukan, akan tetapi masih dibutuhkan usaha strategis dalam meningkatkan kondusifitas madrasah. Dengan demikian, menurut Katsantonis (2020) bahwa iklim sekolah yang kondusif dapat diketahui melalui lingkungan sekolah yang aman, pembelajaran yang produktif, dan partisipasi semua pihak dalam menciptakan lingkungan yang demokratis. 


\section{Partisipasi Masyarakat}

Partisipasi masyarakat dalam penyelenggaraan aktifitas pendidikan merupakan salah satu unsur yang sangat penting dalam kebijakan MBS. Terkait dengan partisipasi masyarakat pada madrasah yang menjadi lokus penelitian ini dapat diketahui berdasarkan hasil wawancara, sebagai berikut:

"Kalau masalah hubungan kita di madrasah dengan masyarakat saya pikir cukup bagus. Karena setiap kita undang untuk mengadakan rapat orangtua siswa hadir terus. Cuma di sini, sebagian siswanya dari daerah yang jauh-jauh. Sehingga terkadang sulit untuk menghadirkan mereka kalau ada undangan rapat. Kalau masalah bantuan dana dari orang tua siswa kita hanya meminta untuk uang semester dan ujian nasional. Karena kasian juga, karena sebagian anak-anak di sini ada yang sudah tidak punya orang tua dan memang secara umum berasal dari keluarga yang kurang mampu. Untuk biaya makannya saja di sini rata-rata dari bantuan panti asuhan. Jadi memang kita tidak bisa berharap banyak dari orang tua kalau masalah dana". (WW/M1_Partisipan 2)

"Kalau untuk partisipasi masyarakat saya pikir sudah bagus. Contohnya di madrasah masih ada biaya sekolah yang dipungut walaupun ada instruksi dari pemerintah larangan untuk memungut uang sekolah dari masyarakat. Tapi, saya pikir itu karena kepala madrasah mampu memberikan pemahaman kepada orang tua terkait dengan biaya yang dibutuhkan di madrasah. Tapi memang setiap ada rapat masalah dana selalu dilaporkan jadi orang tua bisa percaya kemana uang itu digunakan. Selain itu, masih banyak bantuan masyarakat sama madrasah contohnya dulu kita rapat masalah pembuatan pagar dan itu disetujui orang tua. Akhirnya setiap orang tua atau wali dikasi target sesuai dengan kemampuan". (WW/M2_Partisipan 3)

Hasil temuan tersebut menunjukkan bahwa partisipasi masyarakat sudah terbangun sejak berdirinya madrasah. Akan tetapi dukungan secara materiil belum mampu dioptimalkan oleh pihak madrasah dalam memenuhi kebutuhan madrasah itu sendiri. Oleh karena itu, pihak madrasah perlu membangun sinergitas yang baik kepada seluruh stakeholder madrasah, khususnya masyarakat untuk berpartisipasi secara aktif dalam mendukung kegiatan di madrasah, baik melalui dukungan moril maupun materiil. Dengan demikian indikator keberhasilan sekolah/madrasah dalam mengimplementasikan MBS dapat dilihat dari tingkat partisipasi masyarakat dalam proses pendidikan di sekolah/madrasah. Menurut Mulyasa (2012) melalui hubungan yang harmonis antara sekolah dengan masyarakat, maka tujuan hubungan sekolah dengan masyarakat dapat tercapai, yaitu terlaksananya proses pendidikan di sekolah secara produktif, efektif, dan efisien, sehingga menghasilkan lulusan yang produktif dan berkualitas.

Berdasarkan hasil analisis peneliti melalui triangulasi data dan sumber data terhadap ketiga madrasah tersebut bahwa pihak madrasah telah memahami terkait konsep MBS sebagai konsep manajemen di era otonomi dan desentralisasi 
pendidikan. Akan tetapi dalam implementasinya masih belum sesuai dengan konsep MBS yang sebenarnya, seperti didesentralisasikannya berbagai unsur untuk dikelola secara mandiri oleh pihak penyelenggara pendidikan di tingkat madrasah.

Implementasi MBS di MA Muhammadiyah Balebo tidak terlepas dari adanya sikap kekeluargaan dan kebersamaan semua stakeholder, baik pihak internal madrasah maupun dari masyarakat dan juga adanya dukungan dari pengurus Muhammadiyah setempat. Oleh karena itu, menurut analisis peneliti setelah melakukan penelitian bahwa diimplementasikannya MBS di MA Muhammadiyah Balebo disebabkan oleh kesamaan konsep dan pemahaman dari semua pihak dalam menyelenggarakan pendidikan sesuai dengan tujuan pendidikan Muhammadiyah.

Keberhasilan MA Al-Falah Lemahabang dalam mengimplementasikan MBS adalah selain kebersamaan dan konsistensi semua pihak madrasah, juga oleh dukungan masyarakat yang tinggi. Peran kepala madrasah dan pihak yayasan di MA Al-Falah Lemahabang merupakan unsur utama diimplementasikannya MBS. Akan tetapi, terlepas dari hal tersebut, menurut hasil analisis melalui triangulasi data dan juga sumber data didapatkan kesimpulan bahwa selain peran kepala madrasah dan yayasan tersebut, juga tidak terlepas dari adanya ikatan kultur antara pihak madrasah dan masyarakat sekitar sekaligus sebagai pelanggan yang memiliki loyalitas untuk menyekolahkan anaknya di madrasah tersebut.

Sementara, di MAN Luwu Utara ditemukan bahwa implementasi MBS sudah dijalankan walaupun masih belum maksimal. Peran aktif kepala madrasah dalam membangun sinergitas seluruh stakeholder masih perlu ditingkatkan, khususnya komunikasi dengan masyarakat. Keberadaan MAN Luwu Utara sebagai satu-satunya madrasah negeri di Kabupaten Luwu Utara serta ketersediaan dana dan fasilitas madrasah yang cukup merupakan kekuatan dalam mengimplementasikan MBS. Pendekatan multikultural merupakan kekuatan tersendiri bagi Luwu Utara dalam implementasi kebijakan MBS. Hal tersebut ditandai dengan adanya latar belakang guru, siswa dan masyarakat sekitar yang berbeda ideologi, kultur, etnis dan sebagainya. Kekuatan multikultural tersebut, seharusnya menjadi perhatian tersendiri bagi pihak madrasah dalam melahirkan madrasah yang unggul dan kompetitif sebagai ikon madrasah di Kabupaten Luwu Utara.

Implementasi kebijakan yang didesentralisasikan di tiga madrasah di atas, yaitu manajemen kurikulum, tenaga pendidik dan kependidikan, kesiswaan, pendanaan, sarana dan prasarana, iklim madrasah, dan partisipasi masyarakat dianalisis dengan Teori Edward III. Menurut Teori Edward III bahwa dalam implementasi kebijakan dapat dilihat dalam empat aspek, yaitu komunikasi, sumber daya, disposisi dan struktur birokrasi.

Berdasarkan hasil analisis peneliti di MA Muhammadiyah Balebo ditemukan bahwa dalam aspek komunikasi telah berjalan efektif, baik antara kepala madrasah dengan guru, sesama guru, guru dengan siswa, maupun antara pihak madrasah 
dengan masyarakat. Selanjutnya, pemberdayaan sumber daya baik material maupun personal juga sudah dilakukan walaupun belum maksimal, khususnya dalam pemberdayaan SDM madrasah. Disposisi/sikap, khususnya para guru dalam merespon kebijakan yang ada cukup baik. Hal tersebut karena adanya kemunikasi yang baik antara semua komponen madrasah. Sementara peran dan fungsi struktur organsisasi madrasah secara administratif telah dibentuk. Namun, pada ranah implementasi belum berjalan secara maksimal sesuai dengan tanggung jawab masing-masing. Hal tersebut disebabkan karena terjadinya rangkap jabatan dan tugas di luar tugas pokok.

Hasil analisis di MA Al-Falah Lemahabang berdasarkan Teori Edward III bahwa komunikasi antara stakeholder madrasah telah berjalan secara optimal. Hal tersebut disebabkan karena terciptanya nilai kepercayaan, baik dikalangan internal maupun eksternal madrasah (masyarakat). Sehingga implementasi setiap kebijakanya yang diputuskan berjalan secara maksimal sesuai dengan kemampuan madrasah. Sementara dalam aspek optimalisasi sumber daya madrasah juga berjalan secara efektif, baik melalui dukungan moril maupun materiil.

Selanjutnya, dalam aspek disposisi/sikap semua stakeholder dalam mengimplementasikan kebijakan yang telah ditetapkan sudah berjalan secara baik. Mulai dari aspek kurikulum sampai para tingkat partisipasi masyarakat dalam kegiatan di madrasah. Sedangkan optimalisasi peran dan fungsi struktur madrasah sudah berjalan baik, baik ranah administratif maupun implementasi.

Hasil analisis peneliti di MAN Luwu Utara dalam pandangan Teori Edward III bahwa implementasi kebijakan MBS sudah berjalan walaupun belum optimal. Komunikasi antara stakeholder madrasah, juga belum berjalan secara optimal. Hal tersebut disebabkan kemampuan kepala madrasah dalam membangun kultur akademik yang masil lemah dalam menetapkan setiap kebijakan, khususnya dalam hal pendanaan. Sehingga hal tersebut berimplikasi terhadap sikap/disposisi para guru dan staf yang kurang optimal dalam menjalankan tugas sesuai dengan tanggung jawab.

Sementara pemberdayaan sumber daya madrasah di MAN Luwu Utara telah dilakukan secara maksimal, khususnya pengembangan SDM tenaga pendidik. Akan tetapi, optimalisasi peran masyarakat terhadap proses pendidikan di madrasah belum sepenuhnya diakomodir. Hal tersebut, diakibatkan oleh stuktur madrasah yang belum dijalankan sesuai dengan tanggung jawab masing-masing, khususnya di bidang humas.

\section{Faktor Pendukung dan Penghambat Implementasi Kebijakan MBS di MA Muhammadiyah Balebo, MA AI-Falah Lemahabang dan MAN Luwu Utara}

Menjalankan segala sesuatu memiliki sebuah konsekuensi, sehingga maju mundurnya sebuah aktifitas yang kita lakukan merupakan sebuah keniscayaan. Begitu halnya dalam implementasi MBS di madrasah dapat dipastikan bahwa terdapat berbagai macam faktor yang menjadi penghambat dan pendukung. Oleh 
karena itu, dalam menciptakan sekolah/madrasah yang unggul dan produktif, pihak madrasah harus lebih fokus dalam memberdayakan segala potensi sumber daya yang dimiliki. Sehingga yang menjadi faktor penghambat dalam mengimplementasikan MBS secara optimal bukan menjadi persoalan yang dapat mengganggu stabilitas proses pendidikan di madrasah. Hal tersebut sesuai dengan landasan Teori Edward III yang melihat ranah implementasi kebijakan dengan dua faktor utama, yaitu faktor pendukung dan penghambat.

Berdasarkan hasil temuan melalui wawancara, observasi dan dokumentasi terhadap tiga madrasah didapatkan berbagai macam faktor pendukung dan penghambat dalam implementasi MBS di masing-masing madrasah. Berdasarkan hasil analisis peneliti terhadap MA Muhammadiyah Balebo bahwa faktor pendukung dalam mengimplementasikan MBS adalah adanya kerja sama stakeholder yang dilandasi dengan nilai kesadaran dan keikhlasan dalam mengembangkan madrasah, komunikasi yang baik dari pengurus Muhammadiyah baik cabang maupun daerah, serta dukungan masyarakat baik materiil maupun non materiil. Sedangkan faktor penghambat bagi MA Muhammadiyah Balebo dalam mengimplementasikan MBS tidak terlepas dari kurangnya dukungan dana dari orang tua siswa, sedikitnya fasilitas yang menunjang efektifitas dan efesiensi proses pembelajaran, prasarana berupa jalur transportasi yang cukup jauh dari pemukiman warga, dan juga tenaga SDM guru yang rata-rata status honorer.

Selanjutnya, hasil analisis peneliti di MA Al-Falah Lemahabang bahwa faktor pendukung dalam mengimplementasikan MBS adalah tingkat pemahaman pihak madrasah terhadap MBS sebagai model manajemen di tingkat satuan pendidikan, dukungan dari masyarakat baik moril maupun materiil, loyalitas stakeholder yang tinggi, dan hubungan seluruh stakeholder yang harmonis serta menjunjung tinggi budaya kekeluargaan. Sedangkan faktor penghambat terimplementasinya MBS di MA Al-Falah Lemahabang karena adanya instruksi pemerintah terhadap larangan melakukan pungutan biaya pendidikan kepada masyarakat, sehingga menyulitkan pihak madrasah dalam mengatur pendanaan sesuai dengan kebutuhan, juga kurangnya fasilitas yang memadai dalam menjalankan proses pembelajaran yang berkualitas. Selain itu, paradigma berpikir masyarakat di wilayah Kecamatan BoneBone yang masih dominan memilih sekolah umum negeri untuk pendidikan anak mereka.

Hasil temuan di MAN Luwu Utara menunjukkan bahwa faktor pendukung dalam implementasi MBS adalah adanya pemahaman seluruh warga madrasah terkait kemandirian dalam pengelolaan manajemen madrasah, tersedianya fasilitas dan dana yang memadai, dan SDM tenaga pendidik yang kapabel. Sedangkan yang menjadi faktor penghambat adalah terkait pandangan masyarakat terhadap madrasah masih menjadi pilihan kedua setelah sekolah umum, belum munculnya prestasi, serta akses transportasi umum yang belum menjangkau keberadaan madrasah. 
Oleh karena itu, uraian tentang dukungan dan penghambat dalam mengimplementasikan kebijakan MBS di madrasah tersebut menjadi dasar bagi stakeholder madrasah dalam mewujudkan proses pendidikan yang lebih baik. Seperti yang dikemukakan oleh Dwiningrum (2011) dalam mengimplementasikan kebijakan MBS sebagai bentuk otonomi dalam desentralisasi pendidikan dibutuhkan partisipasi masyarakat yang meliputi keikutsertaan dalam perencanaan kebijakan program sekolah/madrasah, keikutsertaan dalam pengawasan mutu pendidikan, dan keikutsertaan dalam pembiayaan pendidikan. Hal tersebut juga diperkuat dengan sebuah pandangan bahwa kemampuan kepala sekolah dalam menata visi, misi dan tujuan serta program sekolah melalui pengembangan kurikulum, penyediaan sarana, peningkatan kualitas SDM, dan partisipasi masyarakat merupakan langkah strategis dalam manajemen mutu sekolah (Baharuddin, 2019).

Respon Guru Terhadap Implementasi Kebijakan MBS di MA Muhammadiyah Balebo, MA Al-Falah Lemahabang dan MAN Luwu Utara

Hasil temuan peneliti terkait dengan respon guru terhadap implementasi kebijakan MBS di tiga madrasah ditemukan berbagai macam respon yang berbeda antara satu madrasah dengan yang lainnya. Hasil temuan di MA Muhammadiyah Balebo, MA Al-Falah Lemahabang dan MAN Luwu Utara menunjukkan bahwa respon para guru terhadap kebijakan implementasi MBS cukup baik. Hal tersebut sesuai dengan hasil wawancara peneliti dengan responden yang memberikan respon prositif terhadap implementasi kebijakan MBS. Respon yang positif tersebut ditandai dengan adanya rasa kepuasan para guru dengan dilibatkannya dalam setiap pengambilan keputusan. Selain itu, juga ditandai dengan adanya komunikasi yang efektif, baik antara kepala madrasah dengan guru maupun diantara sesama guru, sehingga berimplikasi terhadap terciptanya iklim madrasah yang kondusif dengan terbagunnya rasa persaudaraan di internal madrasah.

Berdasarkan hasil analisis tersebut, menunjukkan respon guru terhadap implementasi kebijakan MBS di madrasah cukup bervariasi, sesuai dengan iklim organisasi madrasah. Oleh karena itu, dalam mengimplementasikan kebijakan MBS dibutuhkan keterlibatan aktif para guru melalui kerja nyata dalam proses pembelajaran serta membangun komunikasi yang baik antar sesama warga madrasah. Selain itu, model lain yang dapat diterapkan adalah melalui pembentukan paguyuban sekolah/madrasah. Melalui paguyuban tersebut akan tercipta proses kolektif kolegial dengan mewujudkan fungsinya secara nyata dan tidak hanya sebatas penerima dan pelaksana regulasi atau petunjuk yang bersifat normatif.

\section{PENUTUP/SIMPULAN}

Berdasarkan hasil penelitian yang dilakukan di tiga madrasah, yaitu MA Muhammadiyah Balebo, MA Al-Falah Lemahabang dan MAN Luwu Utara dengan menggunakan analisis Teori Edward III dapat diketahui beberapa pandangan terkait implementasi kebijakan Manajemen Berbasis Sekolah (MBS) sebagai simpulan 
penelitian. Implementasi kebijakan MBS di MA Muhammadiyah Balebo sudah ada sejak berdirinya madrasah tersebut. Sementara, dalam praksis pembelajaran pihak madrasah telah mampu menghasilkan berbagai keputusan yang sesuai dengan kondisi serta kebutuhan madrasah. Selanjutnya, faktor utama yang mendukung dalam mengimplementasikan MBS tidak terlepas dari kerjasama yang baik antara pihak madrasah, masyarakat, dan juga para pengurus Muhammadiyah setempat. Sedangkan faktor penghambatnya adalah kurangnya anggaran yang dikelola oleh madrasah khususnya bantuan dari orang tua siswa, kurangnya fasilitas, serta tenaga SDM pendidik yang masih sebagian besar berstatus honorer. Sedangkan respon guru terhadap implementasi kebijakan MBS cukup bagus. Hal tersebut karena para guru dilibatkan secara langsung dalam setiap agenda yang dilakukan oleh madrasah.

Implementasi kebijakan MBS di MA Al-Falah Lemahabang menunjukkan bahwa semua pihak baik yayasan, madrasah, dan masyarakat turut andil dalam menciptakan efektifitas dan efesiensi di madrasah. Sementara faktor yang mendukung dalam mengimplementasikan kebijakan MBS adalah respon masyarakat yang positif terhadap keberadaan madrasah serta terbangunnya komunikasi yang baik antara seluruh stakeholder madrasah. Sedangkan faktor penghambatnya adalah adanya aturan pemerintah provinsi tentang larangan pungutan biaya terhadap orang tua siswa dan pandangan masyarakat yang masih dominan memilih sekolah umum. Sementara, respon para guru terhadap kebijakan implementasi MBS sangat bagus. Hal tersebut tidak lepas dari kemampuan manajerial kepala madrasah yang cukup baik dalam mengatur sumber daya madrasah.

Implementasi MBS di MAN Luwu Utara sudah berlangsung sejak didirikannya madrasah tersebut, tapi dalam perkembangannya belum bisa dioptimalkan untuk menciptakan proses pembelajaran yang lebih efektif dan efesien. Faktor pendukung dalam mengimplementasikan MBS adalah tersedianya anggaran, fasilitas, dan SDM tenaga pendidik yang memadai. Sedangkan faktor penghambat adalah kurangnya tingkat partisipasi masyarakat, belum berorientasi pada mutu, dan akses transportasi umum bagi siswa ke madrasah. Selanjutnya respon guru terhadap implementasi kebijakan MBS menunjukkan perlunya dilibatkan secara langsung dalam setiap pengambilan keputusan, sehingga prinsip transparansi dan akuntabilitas di madrasah dapat terwujud dalam menciptakan iklim madrasah yang kondusif.

Berdasarkan uraian pada simpulan ini dapat diketahui bahwa kemampuan manajerial kepala madrasah dan partisipasi aktif seluruh stakeholder, khususnya masyarakat dengan dukungan moril dan materiil sesuai kebutuhan madrasah merupakan faktor utama dalam mengimplementasikan kebijakan MBS. Implementasi kebijakan MBS membutuhkan komitmen dan konsistensi semua stakeholder, khususnya kepala sekolah dalam mengoptimalkan fungsi sumber daya sekolah/madrasah. Partisipasi aktif para tenaga pendidik dalam merumuskan 
program madrasah sangat penting. Oleh karena itu, dalam setiap proses pengambilan kebijakan dibutuhkan keterlibatan semua pihak (stakeholder) agar apa yang dirumuskan dapat terealisasi. Hasil kajian ini penting untuk ditindaklanjuti oleh para penggiat pendidikan, khususnya kepala sekolah/madrasah dalam menerapkan manajemen berbasis sekolah yang terintegrasi dengan masyarakat sebagai komponen penting dalam menciptakan iklim pendidikan yang kondusif. Sementara itu, dalam pengembangan literatur akademik kajian MBS masih dianggap perlu untuk diperkuat sebagai pengejawantahan amanah konstitusi khususnya penguatan mutu berbasis desentralisasi pendidikan.

\section{DAFTAR PUSTAKA}

Ahmad, N. S. (2011). Pendidikan dan Masyarakat. Yogyakarta: Sabda Media.

Akib, H. (2010). Implementasi Kebijakan: Apa, Mengapa dan Bagaimana. Jurnal Administrsi Publik, 1(1), 1-11.

Alsayyari, A., dan Et. Al. (2019). Management in Higher Education Institutions: A Conceptual Framework for Facility in Saudi Arabia. TEM Journal, 8(1), 157164.

Asmani, J. M. (2013). Kiat Melahirkan Madrasah Unggulan. Jogjakarta: DIVA Press.

Baharuddin, B. (2019). Manajemen Strategik Mutu Pendidikan. IDaarah: Jurnal Manajemen Pendidikan, 3(1). https://doi.org/https://doi.org/10.24252/idaarah.v3i1.9793

Demirel, F. (2019). The Role of Education in Human Nature and Future Human Design According to Edgar Morin. New Trends and Issues Proceedings on Humanities and Social Sciences, 6(6), 18-29. https://doi.org/10.18844/prosoc.v6i6.4464

Dwiningrum, S. I. A. (2011). Desentralisasi dan Partisipasi Masyarakat dalam Pendidikan. Yogyakarta: Pustaka Pelajar.

Fattah, N. (2012). Analisis Kebijakan Pendidikan. Bandung: PT Remaja Rosdakarya.

Gu, Q., Sammons, P., dan Chen, J. (2018). How Principals of Successful Schools Enact Education Policy: Perceptions and Accounts from Senior and Middle Leaders. Leadership and Policy in Schools, 17(3), 373-390. https://doi.org/10.1080/15700763.2018.1496344

Katsantonis, I. G. (2020). Investigation of the Impact of School Climate and Teachers' Self-Efficacy on Job Satisfaction: A Cross-Cultural Approach. Investigation in Health, Psychology and Education, 10, 119-133.

Lazwardi, D. (2018). Implementation of School-Based Management. AL-IDARAH: Jurnal Kependidikan Islam, 8(1). https://doi.org/https://doi.org/10.24042/alidarah.v8i1.3115 
Majir, A. (2012). Perkembangan Manajemen Pendidikan; Sistem, Teori, Pendekatan dan Inovasi Pembelajaran. Jakarta: CV Cipta Restu Fellynda.

Mulyasa, E. (2012). Manajemen Berbasis Sekolah; Konsep, Strategi dan Implementasi. Bandung: PT Remaja Rosdakarya.

Musanna, A., dan Bahri, S. (2011). Quo Vadis Desentralisasi Pendidikan Di Indonesia Tinjauan Historis, Orientasi dan Reformulasi Desentralisasi Pendidikan. Jurnal IImiah Islam Futura, 10(2), 101-116.

Takdir, M. (2019). Perencanaan SDM dalam Penyelenggaraan Pendidikan. Prosiding Konferensi Nasional IImu Administrasi, 1-6. Retrieved from http://180.250.247.102/conference/index.php/knia/article/download/34/ pdf

Windari, Darwin, dan Purba, S. (2018). Implementation of School Accreditation Policy at State Elementary School in Medan Area District. Advances in Social Science, Education and Humanities Research, 200, 856-860. 